\title{
HOW TO EDUCATIONAL MATERIALS ON THE WEB
}

\section{Jan KUBRICKÝ}

\begin{abstract}
The article is dedicated to creating educational materials on the web from the perspective of teachers. Appropriate topics are discussed concept in determining the objectives, content and technical solutions. The author also deals with the methodology of content creation, or saying the basic principles of teaching materials on the web based on didactic principles.
\end{abstract}

Key words: educational materials, creation, web.

\section{JAK NA VÝUKOVÝ MATERIÁL NA WEBU}

Resumé: Obsah příspěvku je věnován tvorbě výukových materiálů na webu z pohledu učitele. Jsou diskutovány témata vhodné koncepce při stanovení cílů, obsahu a technického řešení. Autor se dále zabývá metodikou tvorby obsahu, respektive vyslovením základních pravidel tvorby výukových materiálů na webu vycházejících z didaktických zásad.

Klićcová slova: výukový materiál, tvorba, web.

\section{1 Úvod}

Počet výukových materiálů se s nástupem a rozvojem internetové služby www geometrickou řadou rozrůstá. Nicméně oddělit ty kvalitní, promyšleně sestavené a $\mathrm{v}$ praxi ověřené nebývá snadnou záležitostí. Zkušený pedagog nejprve vybírá a třídí, hodnotí a analyzuje, a následně využívá těchto materiálů pro podporu své vlastní výuky. Mnohdy ale ani celá řada dostupných výukových zdrojů nesplňuje náročná kritéria využití ve výuce a učitel je nucen vytvořit si vhodný výukový materiál sám. A pro začátek to vzhledem $\mathrm{k}$ množství podílejících se faktorů není otázka okamžitého řešení. Maximální pozornost je potřeba věnovat stanovení konkrétních cílů a požadavků, které aktuální situace vyžaduje. Dále je nutno uvažovat didaktická, technická, estetická a ekonomická hlediska. Podívejme se v tomto příspěvku na bližší specifika tvorby výukových materiálů na webu z pohledu učitele.

\section{Koncepce}

Cílem učitele př̀ tvorbě webového výukového materiálu je nejčastěji zaplnit chybějící mezeru výuky (obsahovou i stimulační) a využít přitom dostupné, ekonomicky přivětivé a technologicky vyspělé služby Internetu (web). Ta nabízí mnohé pokročilé nástroje pro tvorbu interaktivních výukových materiálů a dokáže při správném použití výuku obohatit. V momentě kdy si učitel klade otázky, jak výuku doplnit, jak žáky lépe stimulovat $\mathrm{k}$ práci, jak zakomponovat znalosti z jiných předmětů nebo jak podpořit domácí studium, přichází na řadu stanovení a řešení koncepce, která je podobně jako u tvorby nových učebních pomůcek orientovaná zejména na celkové zvýšeni kvality výuky. V rámci této koncepce učitel nejprve zvažuje propojení výukového materiálu na tematický plán výuky, množství a úroveň zprostředkovaných faktů odpovídající psychické úrovni cílové skupiny žáků, znalosti žáků nabytých z jiných předmětů výuky atd. Následuje projektování technické stránky tvorby výukového materiálu na webu, která musí být úzce spjata se stanovenými faktory koncepce $\mathrm{v}$ předchozím kroku. Tj. učitel nevytváří či nezadává vytvoření jakéhokoliv webu, ale prostředí, které co nejvíce naplňuje požadavky pedagogického působeni na žáky. Více $\mathrm{k}$ technickým řešením výukových webů napřr. v odkazovaném příspěvku (3). Jako poslední přichází na řadu (byt' je to vlastně odrazová či startovní část $\mathrm{k}$ další práci) nasazení výukového materiálu do výuky. Tato fáze zahrnuje pečlivé pozorování a sběr poznatků, které učiteli slouží k posouzení účinnosti výukového materiálu, jeho předností ale i nedostatků, které se bude snažit do budoucna maximálně využit, resp. napravit.

\section{Zásady}

Neodmyslitelnou součástí projektování výukových materiálů na webu je aplikace známých didaktických zásad. Jedná se o náročné a nezbytné promýšlení jednotlivých fází koncepce 
tvorby vlastních výukových materiálů a je potřeba pedagogického mistrovství spolu s trpělivostí a ochotou učitele vracet se $\mathrm{k}$ předchozímu a provádět potřebné úpravy.

Didaktické zásady se musí zřetelně promítnout do metodiky tvorby obsahu, která jak bylo zmíněno výše, je rovněž úzce spjata s technickým řešením prezentace výukového materiálu. Abychom neustále nechodili kolem horké kaše, uved'me si př́iklad. Uvažujme zásadu názornosti, tj. spojení aktivní činnosti, smyslového vnímání a abstraktního myšlení (1). Učitel technického předmětu vidí nutnost zprostředkovat žákům princip činnosti spalovacího motoru jinak, než klasickým náčrtem. Získá výbornou animaci, kterou se rozhodne umístit na webové stránky. Ovšem $\mathrm{s}$ tímto by se neměl spokojit. Co tedy dále. $\mathrm{V}$ této fázi si musí položit výše zmíněné otázky. Na jaké znalosti navázat? S čím obsah propojit? Stránka s animací nesmí osiřet. Učitel by měl využít názorné ukázky k jejímu rozšíření. Doplnit např. o početní př́klady na objem motoru a s ním související výkon. Položit žákům úlohy, aby vyhledali automobily střední třídy, které využívají daný typ motoru. Předložit ukázky alternativních pohonů osobních automobilů s porovnáním účinnosti a ekologického dopadu, atp. Stránka s animací musí vybízet k další činnosti, kzanícení pro pochopení a spojení s ostatním. Technickou stránku je třeba řešit co možná nejdynamičtěji a nejpřehledněji. Klademe nejvyšší důraz na princip činnosti spalovacího motoru, ale zároveň jej využíváme pro syntézu s dalšími souvisejícími oblastmi.

\section{Metodika tvorby obsahu}

Tvorba vlastních výukových materiálů na webu s sebou nese značnou spoustu výhod. Učitel má téměř vše ve svých vlastních rukou. Aktualizace a úpravy výukového materiálu bývají snadné a rychlé. Učitel může $v$ progresivních oblastech (technika, IT) rychle a pružně reagovat na nastalé změny a inovace, podle zpětné vazby od žáků provádí rychlé úpravy a zdokonalení, sdílí obsah se svými kolegy. Pakliže je to možné, vytváŕí na webu interaktivní komunikaci se žáky, podporuje je užívat moderní technologie a rozšiřuje jejich všeobecný rozhled. Výuka je doplněna o moderní a stimulační prvek, lze vhodně střídat režimy práce. Nevýhodou je samozřejmě nutnost potřebného vybavení, technických kompetencí učitele i žáků a pochopitelně určitá nová zátěž na učitele. Nicméně ta se později velmi vyplatí.

Stanovili jsme pracovní verzi základních pravidel pro tvorbu obsahu výukových materiálů na webu. Krom klasicky vyřčených aplikací didaktických zásad předložíme níže uvedené. Technické řešení a jeho pravidla $v$ tomto přehledu nezohledňujeme.

1. Výukové materiály musí být aktuální a pro žáky využitelné.

Za jejich aktuálnost ručí vždy autor. Učivo, které by neodpovídalo aktuálnímu stupni poznání v dané oblasti má pro studující malý význam a v některých př́padech prímo negativní dopad. Je nutná kontrola externích odkazů a dalších, které učitel různě implementuje do výukového materiálu jako celku.

2. Výukové materiály by měly skýtat možnosti rozšiřujicího studia pro nadané žáky.

Web je celosvětová pavučina a využití rozšiřujících materiálů či odkazů na ně by se mělo stát samozřejmostí. Učitel nesmí opomenout ani možnosti, které umožní cílený posun nadaných žáků nebo těch, kteří o konkrétní problematiku projeví oproti ostatním zvýšený zájem.

3. Výukové materiály by mély být kombinovány s klasickými učebními pomůckami.

Neopomínejme klasické učebnice a nesnažme se je přepisovat do podoby www stránek. Dlouhý text čtený z monitoru přináší stagnaci a brzy se dostavující únavu a s tím související odvádění pozornosti nežádoucím směrem. Využívejme počítače především jako prostředníka pro zobrazení multimediálních prvků. Studující vhodně odkazujme na text $\mathrm{v}$ učebnicích a stř́ídejme režim jejich studia. Přispěje to $\mathrm{k}$ lepšímu udržení koncentrace a také $\mathrm{k}$ aktivizaci a zápalu studujících.

4. Výukové materiály na webu by mély motivovat ke studiu.

Jejich obsah a forma by neměla být pouhou strohou informační záležitostí, ale přehlídkou využití aktivních prvků webu směrem k posílení prožitku ze studia. Využívejme překvapivých prvků pro zpevnění učiva a klad'me důraz na multimediální zpestření (pochopitelně v rozumné, pozornost nerušící míre) .

5. Výukové materiály na webu by mély umožňovat zpětnou vazbu.

Zde můžeme opět kombinovat s klasickými učebními pomůckami, např. práci se sešitem. $\mathrm{Na}$ webu poté jen ověřovat správné výsledky 
a hodnotit dosažené pokroky. Kombinace webu a zápisu do sešitu může opět výrazně zpestřit stagnaci čteného textu a aktivizovat studující k činnosti.

\section{Závěr}

Pracovní seznam pravidel by měl začínajícím učitelům posloužit jako základní rámec, který se odvíjí od didaktických zásad. Je pouze na učiteli do jaké míry bude pravidla respektovat a jak budou v jeho praxi krystalizovat. Př́ípadně jak bude učitel definovat ze své zkušenosti pravidla další. Je třeba zkoumat reakce žáků a hodnotit př́nos výuky prostřednictvím výukových webů. $\mathrm{S}$ každým novým publikovaným materiálem se pak posunout dále. Teprve čas a výsledky studujících učitelům ukáže, jak co nejefektivněji publikovat výukové materiály a dosáhnout stanovených cílů.

A ačkoli některé zvěsti pomalu předpovídají konec klasickým učebnicím a sešitům, je takto uvažovat ještě předčasné. Jsou oblasti, kde jsou kniha a učebnice zatím nenahraditelné (2).

\section{Literatura}

[1] SKALKOVÁ, J. Obecná didaktika. 2. rozš. a akt. vyd. Praha: Grada, 2007. ISBN 978-80-2471821-7.

[2] KUBRICKÝ, J., NEUMANN, K. Motivačně-stimulační funkce výukových www stránek. Journal of Technology and Information Education. 2009, Olomouc - EU, Palacký
University, Volume 1, Issue 2, p. 77 - 80. ISSN 1803-537X.

[3] KUBRICKÝ, J. Metodika tvorby výukových materiálů na webu. In Nové technologie ve vzdělávání. Olomouc: Univerzita Palackého, 2011. ISBN 978-80-244-2768-3.

[4] DOSTÁL, J. Multimediální, hypertextové a hypermediální učební pomůcky - trend soudobého vzdělávání. Journal of Technology and Information Education. 2009, Olomouc, Vydala Univerzita Palackého, Ročník 1, Č́́slo 2, s. 18 - 23. ISSN 1803-537X (print). ISSN 18036805 (on-line).

[5] RAMBOUSEK, V. a kol. Výzkum informační výchovy na základnich školách. 1. vyd. Plzeň: Koniáš, 2007. ISBN 80-86948-10-2.

[6] RAMBOUSEK, V. a kol. Technické výukové prostředky. 1. vyd. Praha: SPN, 1989.

[7] PROCHÁZKA, J. Výukové www stránky jako prostředek edukace. In Vzděláváni pro život $v$ informačni společnosti I. 1.vyd. Praha: PdF UK, 2005, s. 117-158. ISBN 80-7290-198-2.

Lektoroval: Mgr. René Szotkowski, Ph.D.

Jan Kubrický, Mgr.,

Katedra technické a informační výchovy, Pedagogická fakulta UP, Žižkovo nám. 5, 77140 Olomouc, ČR, tel. 00420585635806 , e-mail: jan.kubricky@upol.cz Www pracoviště: www.kteiv.upol.cz 